\title{
Host-Parasite Relationships in Fall-Sown Sugar Beets Infected by the Stem and Bulb Nematode, Ditylenchus dipsaci
}

\author{
Pablo Castillo, Institute of Sustainable Agriculture (IAS), Spanish Council for Scientific Research (CSIC), P.O. Box \\ 4084, 14080 Córdoba, Spain; Nicola Vovlas, Istituto per la Protezione delle Piante, Sezione di Bari, Consiglio Nazi- \\ onale delle Ricerche (C.N.R), 70126 Bari, Italy; Andrea Azpilicueta, Newbiotechnic (NBT) S.A., Paseo Bollullos \\ de la Mitación $\mathrm{n}^{\circ}$ 6, Parque Industrial A-49 (PIBO), 41110 Bollullos de la Mitación, Sevilla, Spain; Blanca B. \\ Landa, College of Agriculture and Forestry (ETSIAM), University of Córdoba (UCO), Edificio C4- "Celestino Mu- \\ tis", Carretera de Madrid Km 396, Campus de Rabanales, 14071 Córdoba, Spain, and IAS-CSIC; and Rafael M. \\ Jiménez-Díaz, ETSIAM-UCO, and IAS-CSIC
}

\begin{abstract}
Castillo, P., Vovlas, N., Azpilicueta, A., Landa, B. B., and Jiménez-Díaz, R. M. 2007. Hostparasite relationships in fall-sown sugar beets infected by the stem and bulb nematode, Ditylenchus dipsaci. Plant Dis. 91:71-79.

Stunted growth of fall-sown sugar beets (Beta vulgaris) associated with high incidence of crownroot infections and large soil infestations by Ditylenchus dipsaci were observed at the end of the crop growing season in southern Spain by early June 2005. The largest proportion (75\%) of the nematode life-stages in plant and soil was the fourth-stage juvenile. The large number (up to 3,750 nematodes per gram of fresh tissue) of $D$. dipsaci individuals and severe anatomical alterations observed in storage sugar beet roots suggest that the stem and bulb nematode is the causal agent of the impaired growth of sugar beets observed in commercial fields. Observed morphological traits of nematode specimens and results of specific polymerase chain reaction (PCR) and phylogenetic analyses confirmed that the population of $D$. dipsaci infecting sugar beet belongs to the normal (nongiant) biological type of the nematode. Results of host-range bioassays indicated that the population of $D$. dipsaci infecting sugar beet in southern Spain reproduces on pea (including seeds and pods), onion, potato, spinach, and tomato, but not on bean, cotton, maize, and tobacco. These results indicate that $D$. dipsaci may be an important constraint for sugar beet crops in the affected area, but also for other important crops commonly used in rotation with them.
\end{abstract}

Additional keywords: emerging disease, histopathology, phenotypic and molecular diagnosis

Ditylenchus dipsaci, the stem and bulb nematode, is an obligate migratory plantparasitic nematode that feeds within parenchymatous tissues of about 500 plant species. The nematode damages stems of herbaceous plants such as alfalfa, beans, and pea; bulbs such us daffodil, garlic, narcissus, and onion; and taproots of plants such as carrot and sugar beet, causing stunting, swelling, and rotting that result in significant economic losses (37). This nematode is one of the most cosmopolitan and serious nematode plant pathogens, with distribution worldwide but mainly in temperate zones, including the Mediterranean Basin. D. dipsaci's cryptobiotic state

Corresponding author: P. Castillo

E-mail: ag1cascp@uco.es

* The $\boldsymbol{e}$-Xtra logo stands for "electronic extra" and indicates that Figures 1 and 6 appear in color in the online edition.

Accepted for publication 28 August 2006.

DOI: 10.1094/PD-91-0071

(C) 2007 The American Phytopathological Society enables it to survive below $0^{\circ} \mathrm{C}$ winter temperatures or decades of desiccation (37). According to present knowledge, $D$. dipsaci should be considered as a species complex consisting of many races and populations that differ mainly in host range and appear to be at different stages of speciation $(37,38)$. The phenotypic characterization of biological races in $D$. dipsaci has been shown to be impractical since host plants and temperature affect the nematode morphometry. The only exception for that is the giant race, which usually infects faba bean and can be differentiated from the other biological races by its significantly greater body length $(8,36)$. Recently, Esquibet et al. (9) and Subbotin et al. (38) developed a multiplex polymerase chain reaction (PCR) assay, based on sequence-characterized amplified regions (SCAR), which allows for the genotypic characterization of the giant and the normal races of $D$. dipsaci. Also, a speciesspecific primer pair was developed for the detection and quantification of $D$. dipsaci sensu stricto.

In Spain, sugar beet (Beta vulgaris L.) is cultivated in three large geographical areas at the northern, central, and southern parts of the country. The crop is sown in springtime in the northern and central areas because of lower temperatures compared with those in the southern area, where sugar beet is sown in the fall. Fall-sown sugar beet also is common in certain areas of North and South America and in irrigated clay-loam soils of the Mediterranean Basin. In all these geographic areas, sugar beet develops from fall to late spring, under wet environmental conditions that may favor attacks by the stem and bulb nematode. Infections by $D$. dipsaci and damage to sugar beet have been reported in several sugar beet production areas of the world, including Canada (19), France (3), England (28), Germany $(5,29)$, Hungary (26), Iran (7), Morocco (30), Netherlands (20), Romania (24), Serbia (18), Switzerland (15), and Ukraine (33). However, the disease has not been reported in sugar beets in the United States (37) and Spain. D. dipsaci is considered a serious pathogen of sugar beet only in Switzerland (15) and Germany, especially in the Bonn and Rhineland sugar beet production areas $(5,29)$.

While conducting sugar beet disease surveys in the Seville province, southern Spain, at the end of the growing season in early June 2005, we observed high incidence of crown-root infections, stunted aboveground plant growth, and large soil infestations of $D$. dipsaci. To our knowledge, this is the first report of natural infections and severe damage to sugar beet caused by the stem and bulb nematode in Spain. This detection suggests that this nematode may be a new and emerging phytopathological problem of sugar beet production in this area. Therefore, the objectives of this study were to determine: (i) the identity of the stem and bulb nematode population infecting sugar beet in southern Spain by means of reliable diagnostic procedures; (ii) the host-parasite relationships of the stem and bulb nematode in sugar beet storage roots infected by the nematode; and (iii) host-status for this D. dipsaci population infecting sugar beet of current or potential alternative crops used in rotation in areas infested by the nematode. 


\section{MATERIALS AND METHODS}

Nematode diagnosis. Ten samples of storage roots of sugar beet 'Abril' together with rhizosphere and bulk soils were taken arbitrarily with a shovel from the upper 30 $\mathrm{cm}$ of soil from five commercial fields at Lebrija, Seville province, southern Spain. Nematodes were extracted from soil samples by centrifugation (4) and identified based on microscopic observations of glycerin-infiltrated specimens extracted from soil and plant tissues (32). Morphological identification of the stem and bulb nematode was further confirmed by species-specific molecular markers that differentiate normal and giant populations (9), as well as conventional PCR amplification and phylogenetic analysis of the full ITS region of rDNA (ITS1-5.8S-ITS2) (38).

Total genomic DNA was extracted from 2, 5, or 10 adult females according to methods of Esquibet et al. (9). To differentiate between normal and giant types of $D$. dipsaci, two pairs of SCAR primers were used in single (primers H05/H06, normal type) and duplex (primers D09/D10, giant type $+\mathrm{H} 05 / \mathrm{H} 06$, normal type) PCR assays with the reaction conditions described by Esquibet et al. (9). The ITS1-5.8S-ITS2 region of rDNA was amplified using the primer set $5367 / 26 \mathrm{~S}$ as described by Wendt et al. (40), and a restriction fragment length polymorphism (RFLP) analysis of the amplicon was conducted using four enzymes, HaeIII, HinfI, RsaI, and TaqI $(9,40)$. Fragments shorter than 50 bp were not considered for comparison in the RFLP analysis.

All amplifications were performed with a PTC 200 thermocycler (MJ Research, Bio-Rad Laboratories, Madrid, Spain). Amplification products were separated by electrophoresis in 1.5 or $2 \%$ (RFLP analysis) agarose gels in $1 \times$ TAE buffer for 2 to $3 \mathrm{~h}$ at $100 \mathrm{~V}$, stained with ethidium bromide, and visualized under UV light. The AmpliSize 50 to 2,000 bp ladder (Bio$\mathrm{Rad}$ ) was used for electrophoresis. Amplifications were repeated at least twice and always included negative controls (no DNA) and positive control DNA extracted from adult $D$. dipsaci females of a reference garlic isolate (normal population) from Córdoba (southern Spain). This nematode isolate is maintained at the nematode collection of the Institute of Sustainable Agriculture-CSIC, Spain.

After amplifications, the ITS1-5.8SITS2 amplicons were purified with a gel extraction kit (Geneclean turbo; QBIOgene S.A., France), quantified using the Quant-iT DNA Assay Kit Broad Range fluorometric assay (Molecular Probes, Inc.) with a Tecan Safire fluorospectrometer (Tecan Spain, Barcelona, Spain) according to manufacturer's instructions, and used for direct DNA sequencing. DNA fragments from two independent PCR amplification assays were sequenced in both directions using the same amplifica- tion primers with a terminator cycle sequencing ready reaction kit (BigDye; Perkin-Elmer Applied Biosystems, UK) according to the manufacturer's instructions. The resulting products were purified and run on a DNA multicapilar sequencer (Model 3100 genetic analyzer; Applied Biosystems, UK) at the University of Córdoba sequencing facilities. The ITS sequences of $D$. dipsaci reference isolate from garlic, as well as of an isolate from sugar beet, were deposited as GenBank Accession DQ520932 and DQ520931, respectively.

Bionumerics 4.5 software (Applied Maths, Kortrijk, Belgium) was used to align the two sequences of $D$. dipsaci from this study with 27 ITS1-5.8S-ITS2 published sequences of $D$. dipsaci used by Subbotin et al. (38), 14 new D. dipsaci ITS sequences obtained from GenBank (AY703059AY703065, AY714535-AY714541; M. Kerkoud, M. Esquibet, O. Plantard, M. Avrillon, C. Guimier, M. Franck, J. Lechappe, and R. Mathis, unpublished), and an ITS sequence of $D$. destructor as outgroup taxon (AY987007). Phylogenetic trees were generated by the neighborjoining (NJ) and maximum parsimony (MP) method with UPGMA cluster analysis using Bionumerics 4.5 software. The phylograms were bootstrapped 1,000 times to assess the degree of support for the phylogenetic branching indicated by the optimal trees.

Histopathology. Storage roots of sugar beet 'Abril' naturally infected by $D$. dipsaci were arbitrarily selected from five commercial fields at Lebrija, Seville province for histopathological studies. To determine the level of infection in different zones of the sugar beet storage roots, $10 \mathrm{~g}$ of infected (crown-canker) storage roots were taken from 10 arbitrarily selected sugar beets at: leaf base, crown-root (approximately 3 to $5 \mathrm{~cm}$ above soil level), medium storage root zone $(10$ to $15 \mathrm{~cm}$ depth), and deep taproot zone $(>20 \mathrm{~cm}$ deep). Nematodes from tissues of those different root zones were extracted by maceration-centrifugation (4), and nematode populations per gram of fresh infected tissue were estimated. Additionally, nematodes extracted from plant tissues were classified according to life-stages based on sexual characters (presence of vulva or spicules) in adults, body length, and development of genital primordium and rudiments of vulval slit or spicular pouch in juvenile stages (41). Because of the large nematode populations in some samples, a subsample with a maximum of 100 specimens was randomly selected for further observations.

Small portions $(5 \times 5 \times 5 \mathrm{~cm})$ of naturally infected sugar beet storage roots were arbitrarily selected from crown-root, medium taproot zone, and deep taproot zone. These portions, along with that of healthy storage roots, were washed gently free of adhering soil and debris, and used for histological examination. Tissues were fixed in formaldehyde chromo-acetic solution for $48 \mathrm{~h}$, dehydrated in a tertiary butyl alcohol series (40-70-85-90-100\%), embedded in $58^{\circ} \mathrm{C}$ melting point paraffin, and sectioned with a rotary microtome. Sections, 10 to 12 $\mu \mathrm{m}$ thick, were placed on glass slides, stained with safranin and fast-green, mounted permanently in $40 \%$ xylene solution of a polymethacrylic ester (Synocril 9122X, Cray Valley, NJ), examined microscopically, and photographed (22).

Quantitative data obtained from the evaluation of developmental life-stages from the different regions of sugar beet taproot were subjected to analysis of variance using Statistix 8.0 (NH Analytical Software, Roseville, MN). Means values were compared using Fisher's protected least significant difference test at $P=0.05$ (13).

Host range study. Ten plant species were used: bean (Phaseolus vulgaris L. 'Nectar'), cotton (Gossypium hirsutum L. 'Conchita'), maize (Zea mays L. 'Simon'), onion (Allium cepa L. 'Valenciana'), pea (Pisum sativum L. 'Lincoln'), potato (Solanum tuberosum L. 'Kennebec'), spinach (Spinacia oleracea L. 'Viroflay'), sugar beet ('Abril'), tobacco (Nicotiana tabacum L. 'NC 95'), and tomato (Lycopersicon esculentum Mill. 'Tres Cantos'). Seeds and potato-tuber pieces were surface-disinfested with $2 \% \mathrm{NaOCl}$ for 3 min and germinated on sterile, moistened filter paper in petri plates at $25^{\circ} \mathrm{C}$ in darkness for 48 to $72 \mathrm{~h}$. Germinated seeds, selected for uniformity, were sown into $15-\mathrm{cm}$ diameter clay pots (one seed per pot) filled with $500 \mathrm{ml}$ of an autoclaved $\left(121^{\circ} \mathrm{C}\right.$ for 1 $\mathrm{h}$, twice on 2 consecutive days) soil potting mixture (sand:clay loam, 2:1, vol/vol), infested or not with the nematode.

The nematode population used in this experiment was obtained from monoxenic carrot ('Nantesa') disk cultures starting from a single gravid female obtained from infected sugar beet at Lebrija (Seville). Single females were surface-disinfested with $0.02 \%$ ethoxyetil mercury chloride and $0.1 \%$ streptomycin solutions for 2 and $24 \mathrm{~h}$, respectively, and then thoroughly rinsed several times in sterile distilled water. Inoculum was increased successively on carrot disks incubated at $20^{\circ} \mathrm{C}$ for 4 to 6 weeks each time (2). Nematodes were extracted from carrot disks by maceration-centrifugation (4). Nematode population density was determined from $1-\mathrm{ml}$ aliquot of water suspension. Then, $1 \mathrm{ml}$ of sterile distilled water with nematode inoculum (400 nematodes with mixed life stages) was placed directly on the seeds at the time of sowing, and the seeds were immediately covered with a thin layer of wet, autoclaved soil potting mixture to prevent the seeds from being washed out of the soil during watering. Control plants of each plant species were treated similarly 
with sterile distilled water except for absence of nematode inoculum.

Plants in pots were grown in a phytotron (Sanyo Gallencamp PLC, Fitotron Leicester, England) adjusted to precise temperature of $20^{\circ} \mathrm{C}, 60$ to $80 \%$ relative humidity, and a 14-h photoperiod of fluorescent light of $360 \mu \mathrm{E} \cdot \mathrm{m}^{-2} \cdot \mathrm{s}^{-1}$ for 45 days. Plants were watered as needed and fertilized with 100 $\mathrm{ml}$ of a $0.1 \%$ solution of $20-5-32+$ micronutrients hydro-sol fertilizer (Haifa Chemicals Ltd., Haifa, Israel) every week.

The experiment was arranged in a completely randomized design with six replicates, each replicate consisting of a single potted plant. The experiment was repeated once, and similarity between experiments was tested by preliminary analyses of variance using experimental runs as blocks. Data of nematode populations in soil as well as reproduction index were transformed before analysis into $\log _{10}(X+1)$ (13). The experiment finished 45 days after inoculation. Then, each individual plant was separated, the roots washed free of soil, and nematode population densities in both aboveground organs of every crop specie as well as storage roots of sugar beet and soil were assessed. Nematodes were extracted from the entire above-
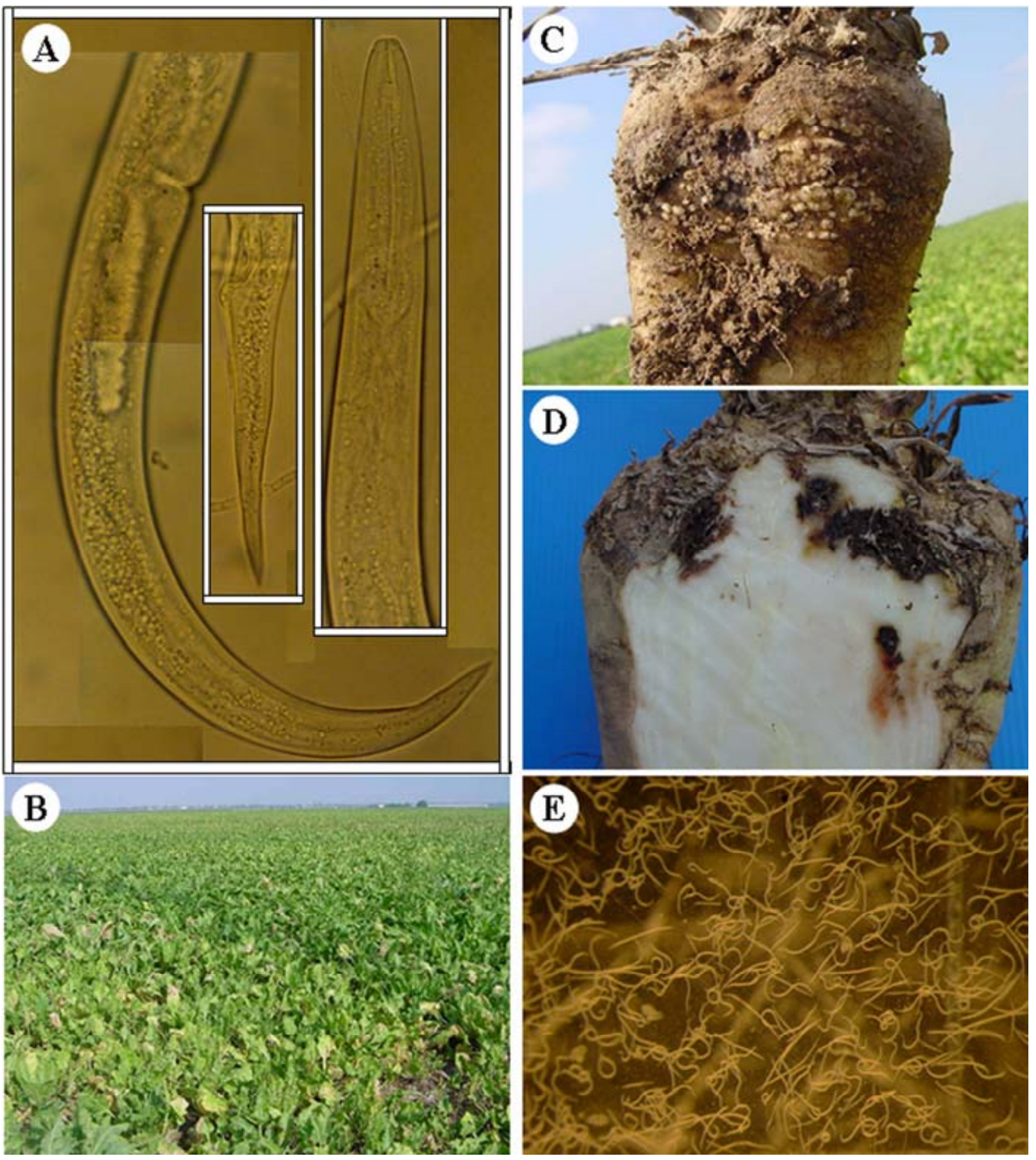

Fig. 1. Damage by the stem and bulb nematode, Ditylenchus dipsaci, on sugar beet. A, Details of diagnostic features of the nematode. B, Commercial field of sugar beet in Lebrija, Seville, southern Spain, showing a patch severely damaged by the nematode. C and D, Crown-root cankers. E, Live specimens extracted from infected tissues. 
ground organs and storage roots of sugar beet by maceration-centrifugation (4); and from $100 \mathrm{~cm}^{3}$ of infested soil per pot by maceration-flotation (4), to estimate final nematode population densities per crop species and to calculate the reproduction factor $(\mathrm{Rf}=\mathrm{Pf} / \mathrm{Pi})$ values.

\section{RESULTS}

Nematode diagnosis. Detailed morphometric observations based on female and male body length, stylet length, as well as the de Man's ratios, were concordant with those that characterize normal biological races of D. dipsaci (Fig. 1A).
PCR assays using DNA extracted from sugar beet-infecting nematodes at Lebrija and the D. dipsaci reference isolate from garlic, and SCAR primer pair $\mathrm{H} 05 / \mathrm{H} 06$, gave rise to the $D$. dipsaci marker amplicon of 242 bp characteristic of the normal type (Fig. 2A, lanes 1, 2, 4, and 7 and 3, 5, and 8 , respectively). Similar results were obtained from those same DNA samples using the H05/H06 primers together with primer pair D09/D10 (specific for the $D$. dipsaci giant type) in a duplex PCR assay, but no amplification of the 198-bp DNA fragment marker of the giant population occurred (Fig. 2B).

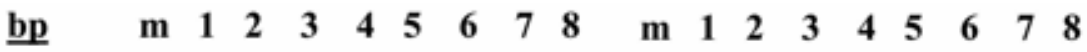
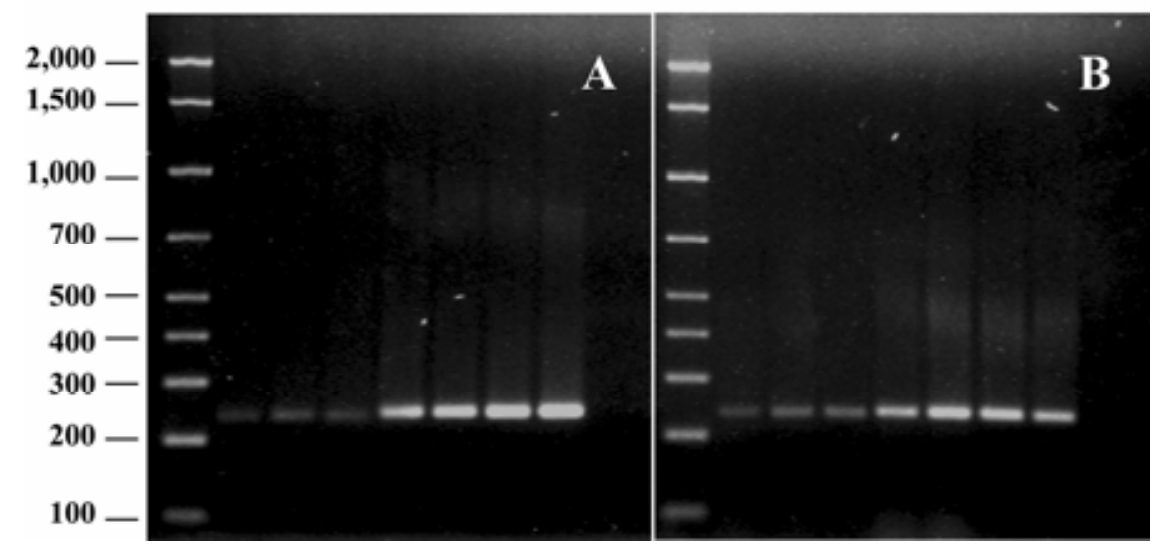

Fig. 2. A, Agarose gel electrophoresis of polymerase chain reaction (PCR) amplified sequencecharacterized amplified region (SCAR) markers for normal and giant type of Ditylenchus dipsaci using two pairs of SCAR primers used in (A) single (H05/H06, normal type) or (B) duplex (D09/D10 giant type $+\mathrm{H} 05 / \mathrm{H} 06$, normal type) PCR assays. DNA was extracted from 2, 5, and 10 adults of $D$. dipsaci population from sugar beet (lanes 1,2, 4, and 6, respectively), or from 2, 5, and 10 adults of $D$. dipsaci population from garlic (lanes 3,5, and 7, respectively); $m=$ AmpliSize molecular weight marker (Biorad, Madrid, Spain); lane $8=$ negative control.

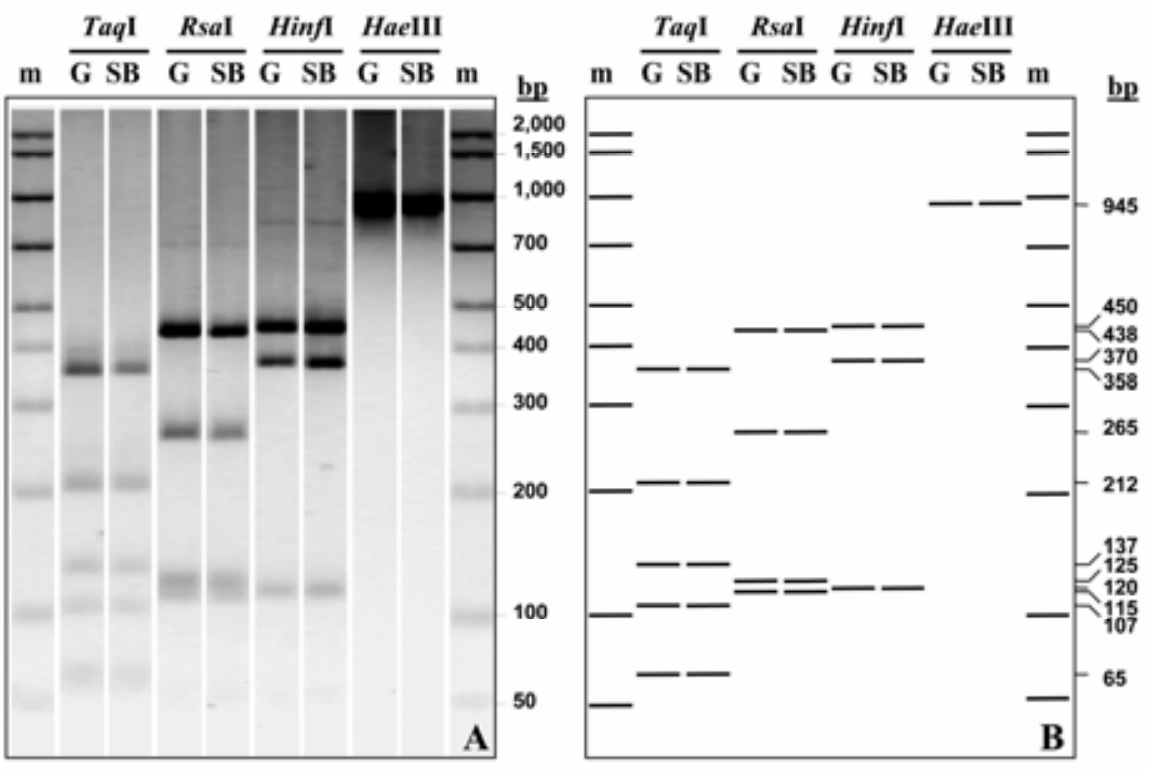

Fig. 3. Agarose gel electrophoresis of restriction fragments of polymerase chain reaction (PCR) amplicons from internal transcribed spacer (ITS) regions of Ditylenchus dipsaci using 5367/26S primer pair digested with HaeIII, HinfI, RsaI, and TaqI restriction enzymes. A, Agarose gel electrophoresis image; B, restriction fragment length polymorphism (RFLP) sizes estimated using Bionumerics 4.5 software (Applied Maths, Kortrijk, Belgium). $\mathrm{m}=$ AmpliSize molecular weight marker (Biorad, Madrid, Spain); $\mathrm{G}=$ D. dipsaci population from garlic; $\mathrm{SB}=D$. dipsaci population from sugar beet.

Amplification of the ITS region including the flanking parts of the $18 \mathrm{~S}$ and $28 \mathrm{~S}$ genes yielded a single fragment of approximately $1 \mathrm{~kb}$ for both the garlic and sugar beet nematode populations. RFLP patterns generated with each of four restriction enzymes were identical for the two populations (Fig. 3).

The pair-wise divergence of the ITS15.8S-ITS2 sequences varied from 0 to $1 \%$ among $D$. dipsaci populations from garlic and sugar beet and members of $D$. dipsaci sensu stricto (38), and that divergence varied within 0 to $8 \%$ when all populations within the $D$. dipsaci complex were compared. NJ and MP analyses of the ITS15.8S-ITS2 alignments generated trees with similar topology that comprised two main clades: (i) a clade that contained the reference garlic and sugar beet populations, all isolates considered as members of $D$. dipsaci sensu stricto by Subbotin et al. (38) from cultivated plants, and some isolates from ornamental and wild plants; and (ii) a clade divided into different groups, including: a first subclade with populations of the "giant race" from bean considered as Ditylenchus sp. B by Subbotin et al. (38) and six isolates from Vicia faba L. obtained by M. Kerkoud, M. Esquibet, O. Plantard, M. Avrillon, C. Guimier, M. Franck, J. Lechappe, and R. Mathis, (unpublished results); four subclades $(\mathrm{C}, \mathrm{D}, \mathrm{E}$, and F) with Ditylenchus spp. populations from different Asteraceae genera (38); and a final subclade, G, grouping Ditylenchus sp. from Plantago maritima L. (38). Only the optimum MP tree obtained is shown in Figure 4.

The soil from five commercial fields of sugar beet 'Abril' was highly infested with D. dipsaci (78 nematodes per $100 \mathrm{~cm}^{3}$ of dry soil). Analysis of the nematode developmental life-stages in soil samples collected toward the end of growing season showed that fourth-stage juveniles (J4) predominated in the population $(89.7 \%)$, with the second- and third-stage juveniles (J2-J3) being $9.0 \%$ of that, and adult females and males were at the lowest proportion $(1.3 \%)$. Plant-parasitic nematodes detected in soil samples also included Helicotylenchus pseudorobustus, Merlinius brevidens, and Tylenchorhynchus sp., with average populations of only 3,5 , and 1 nematodes $/ 100 \mathrm{~cm}^{3}$ of soil, respectively. Symptomatic, damaged sugar beet plants were grouped in distinct patches in the field (Fig. 1B). Plants infected with $D$. dipsaci showed foliar chlorosis, light deformation of foliage, and scarce enlargement of the buds at crown level (Fig. 1C and D).

Histopathology. Assessment of population densities of $D$. dipsaci developmental life-stages in sugar beet storage root tissues showed that $\mathrm{J} 4$ was the most significantly abundant $(P<0.001)$ life-stage irrespective of the sampled root zones, with a proportion of about $75 \%$ (68.7 to 
$89.7 \%$ ) of the total life-stages (Fig. 5). On the contrary, adult stages represented the least proportion (1.1 to $10.0 \%$ ) in all storage root zones (Fig. 5). Extensive, rough necrotic zones or cracks were observed on the surface of crown-root toward the end of the crop season, by early June. Later, the tissue degradation extended deeper into the crown-roots (Figs. 1C and D). Despite the heavy damage, green leaf tissues remained fresh in most plants as long as the vascular bundles were not affected, and water and nutrients appeared to continue reaching the leaves (Fig. 1B). Diseased crown-root tissues displaying the characteristic symptoms (Figs. 1C and D) contained females, males, juveniles, and embryonated eggs of $D$. dipsaci. Examination of mature, infected crown-roots revealed that the nematode had invaded the epidermis, the cortical storage parenchyma, and the primary xylematic tissues (Fig. 6). Nematode migration and feeding in cortical storage parenchyma tissues caused separation of cells, resulting in the enlargement of intercellular spaces. When nematodes fed intensively in cortex tissues, they induced extensive cell separation, and necrosis developed between contiguous cells which caused the formation of large cavities (Figs. 6A and B). Nematodes in this tissue were found inter-, but not intracellularly (Figs. 6C to $\mathrm{H}$ ). The nematode feeding sites were at the greatest frequency beneath the crown-root, and the lowest one occurred in deeper storage root regions. Cells, especially the smaller ones, became more spherical as they enlarged. As cells separated, the cytoplasm was withdrawn from cells, the walls of which collapsed to form a cavity around the nematode; hyperplasia was not observed (Figs. 6E and F). Neither the density of the cytoplasm nor the number of nuclei per cell increased, but some nuclei were deformed. Walls of cells around the nematode collapsed when most of the cytoplasm had been removed, so that the cavities forming around the nematode often coalesced.

Host range study. By the end of the experiments, the final population density of D. dipsaci in soil was highest $(P<0.001)$ in pot soil grown to onion, and lowest $(P<$ $0.001)$ in pot soils grown to tomato and maize (Table 1), although overall those populations were close to initial inoculum (Table 1). On the basis of nematode reproduction rate $(R f)$ in aboveground plant parts and storage roots, it appears that the sugar beet $D$. dipsaci isolate from Lebrija is not parasitic to bean, cotton, maize, and tobacco (Table 1), but parasitic to onion, pea (including seeds and pods, 2 to 4 nematodes per seed, and 2 to 24 nematodes per pod), potato, spinach, sugar beet, and tomato (Table 1). The $R f$ values of that $D$. dipsaci isolate in onion, pea, potato, spinach, sugar beet, and tomato were larger than 1.0, indicating that these plants are suitable hosts for D. dipsaci. Among those six plants, pea, onion, and spinach were the most suitable hosts for the nematode, followed by potato and sugar beet, and finally tomato (Table 1). In addition, reproduction of $D$. dipsaci was significantly greater $(P<0.001)$ in onion, pea, and spinach compared with that in the remaining plant species (Table 1), with tomato showing the lowest reproduction rate (Table 1). Bean, cotton, and maize green tissues were barely infected by the nematode (i.e., nematode populations ranging from 1 to 12 nematodes per gram of tissue).

\section{DISCUSSION}

In southern Spain, sugar beet is an important alternative and break crop for crop rotations in sustainable agriculture, compared with the regular use for rotations of other fall-sown crops, such as cereals. However, the fall-sown sugar beet characteristic of southern Spain forces the crop to develop the vegetative cycle during the winter and spring, when environmental conditions are favorable for attacks by several diseases of diverse etiology (such as crown tumor caused by Physoderma leproides, and leaf spot caused by Cercospora beticola). Disease surveys conducted in commercial sugar beet fields by the end of the crop season in southern Spain revealed high soil infestation and high rates of crown-root infections by the stem and bulb nematode. The stem and bulb nematode was the only plant-pathogenic nematode present in sufficient numbers in affected tissue to cause damage to sugar beet root and crown. Although lower numbers of some other species and genera of plantparasitic nematodes, such as stunt $(M$. brevidens, Tylenchorhynchus sp.) and spiral (H. pseudorobustus) nematodes, were recovered from soil around roots and plants sampled, they were considered not harmful factors to the sampled plants because they have not been reported to be serious pathogens of sugar beet (34).

The stem and bulb nematode has been reported to cause high harvest losses in sugar beet ranging from 10 to $50 \%$ in Switzerland (14), and about $60 \%$ in Germany (11). Apart from yield loss, infection by $D$. dipsaci can cause a decrease in the sugar and dry matter contents of affected

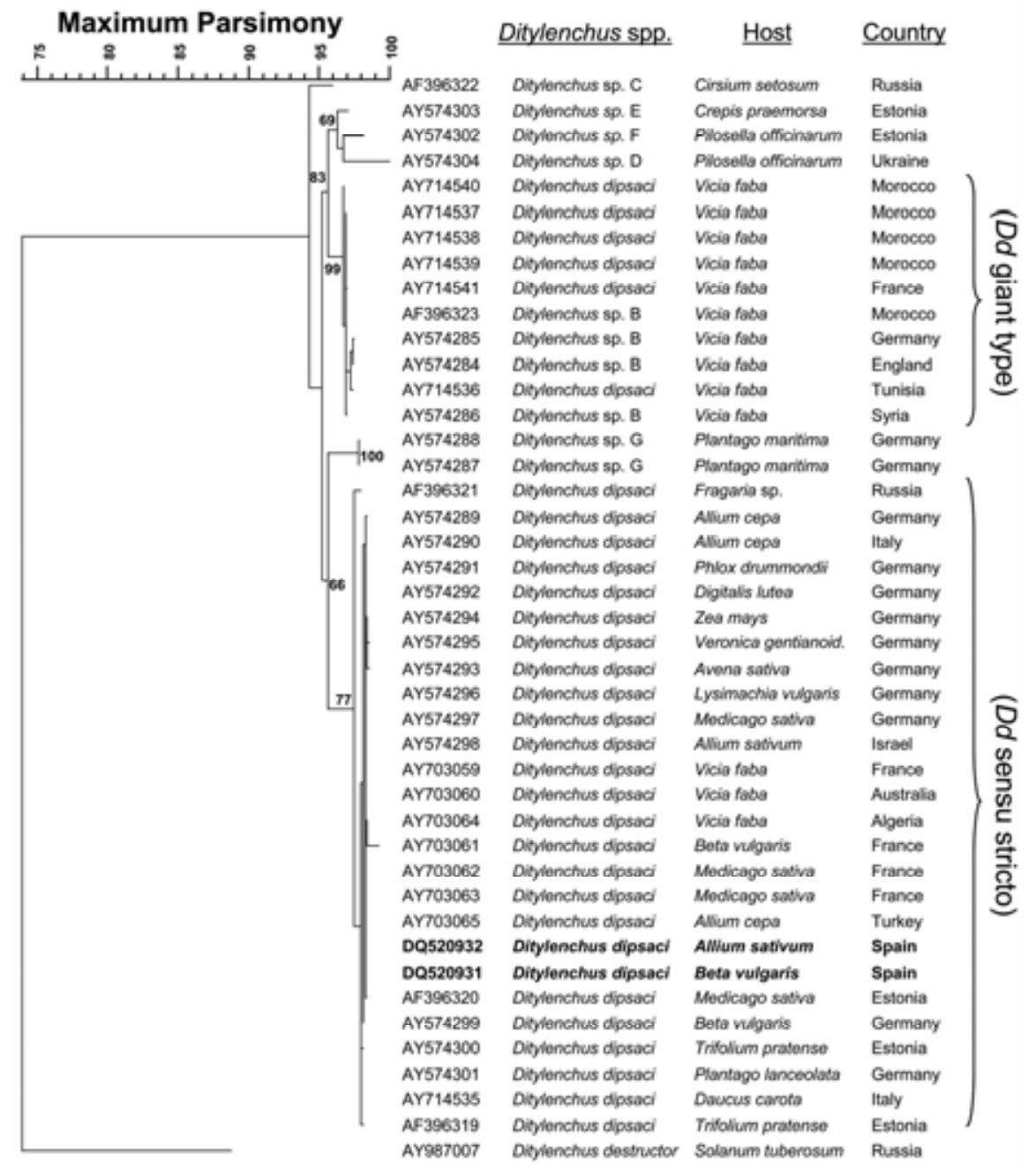

Fig. 4. Maximum parsimony tree resulting from analysis of alignments of internal transcribed spacer 1 (ITS1)-5.8S-ITS2 sequences of the Ditylenchus dipsaci species complex and D. destructor as outgroup. Bootstrap supports more than $50 \%$ are given for appropriate clade. 

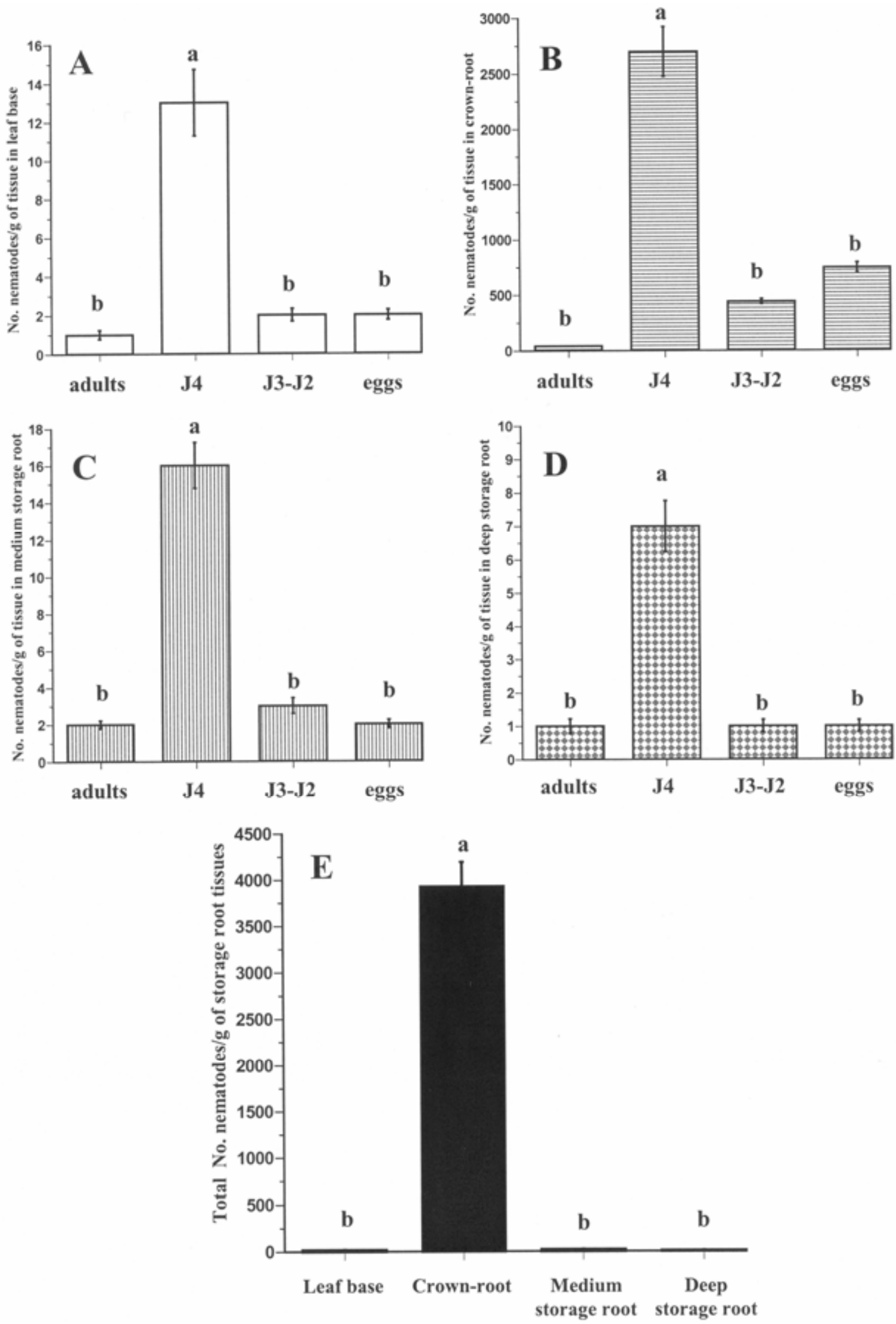

Fig. 5. Population densities per gram of tissue of Ditylenchus dipsaci developmental life-stages in naturally infected zones of sugar beet (cv. Abril) storage roots sampled by the end of the growing season from two commercial fields at Lebrija, Seville province (southern Spain). A, Nematodes in leaf base. B, Nematodes in crown-root (approximately $5 \mathrm{~cm}$ above soil level). C, Nematodes in medium taproot zone (10 to $15 \mathrm{~cm}$ depth). D, Nematodes in deep taproot zone ( $>20 \mathrm{~cm}$ deep). E, Total nematode populations in each plant tissue. Each value is the mean ( \pm standard error) of $10 \mathrm{~g}$ of plant tissues from 10 infected sugar beet storage roots. Bars followed by common letters do not differ significantly $(P \geq 0.05)$ according to Fisher's protected least significant difference. 

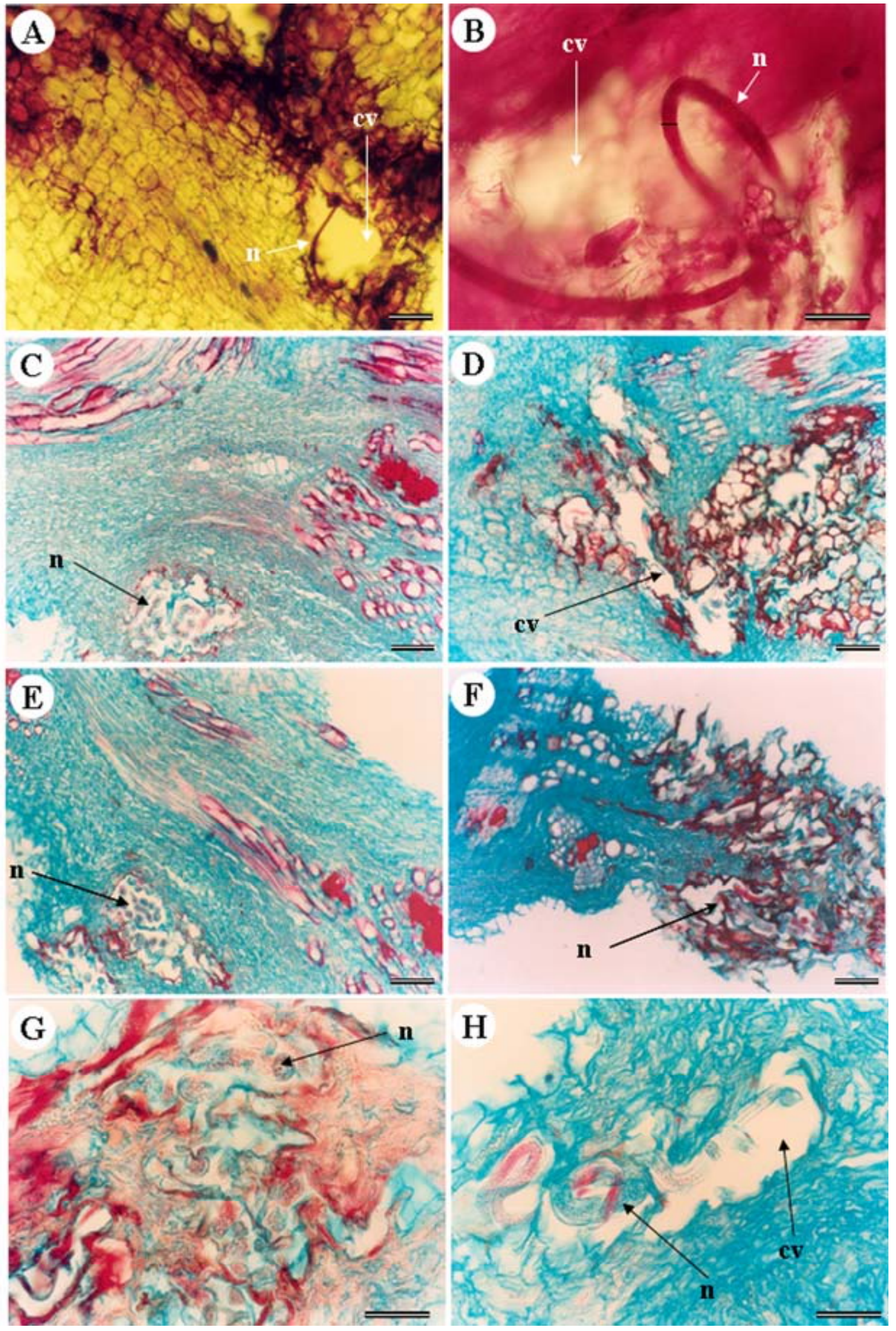

Fig. 6. Transverse sections of storage roots of sugar beet cv. Abril severely infected by Ditylenchus dipsaci. A and B, Nematode infection of storage roots showing necrosis and cavities (cv) around the nematode (n). C to F, Feeding areas on meristematic tissues showing nematode colonies (n) and large necrotic areas and cavities (cv). G and $\mathbf{H}$, Higher magnifications of feeding sites showing different life-developmental stages of the nematode. Scale bars: $\mathbf{A}, \mathbf{C}$ to $\mathbf{F}$ $=200 \mu \mathrm{m} ; \mathbf{B}, \mathbf{G}, \mathbf{H}=100 \mu \mathrm{m}$. 
roots, as well as increase of secondary products undesirable for the industrial procedures of sugar production, even in the absence of visible symptoms $(23,29)$. In this present study, the high level of $D$. dipsaci found in soil and sugar beet storage roots under natural conditions, as well as the anatomical alterations observed in infected storage roots, suggest that parasitism of sugar beets by the stem and bulb nematode may impair growth of the plant and thus contribute to decreased potential sugar yield and quality.

The accurate biological identification and pathogenic characterization of the stem and bulb nematode infecting a crop is a prerequisite for designing effective confor sugar beet in southern Spain where $D$. dipsaci appears to be a newly emerging and threatening pathogen of fall-sown crops for which disease control measures are yet to be identified and management strategies designed. The usefulness of identifying biological races in the stem and bulb nematode is highly questionable, because some biological races showed extremely broad host range and interbred freely, giving rise to fertile progenies, which makes the identification and delimitation of a biological race in $D$. dipsaci not possible in many cases $(35,37,39)$. This is also the case with populations of nematodes attacking sugar beet, which is a suitable host for various $D$. dipsaci races (37). In our study, the observed morphological traits of the nematode as well as the specific PCR assays and phylogenetic analysis carried out confirmed that the population of $D$. dipsaci infecting sugar beet in southern Spain belongs to the normal biological type of the nematode $(9,21,38)$.

RFLP analyses gave rise to identical patterns for populations from garlic and sugar beet, which agree with Wendt el al. (40), trol strategies. This is particularly relevant

who failed to discriminate between $D$. dipsaci isolates of the normal type from different hosts, although they could distinguish between the giant and normal types of the nematode. Also, similar to our results, Subbotin et al. (38) could differentiate two main clades among the $D$. dipsaci complex using phylogenetic analysis of the full ITS1 and ITS2 sequences based on minimum evolution, maximum parsimony, and Bayesian inference. In that study, the first clade comprised diploid isolates of $D$. dipsaci sensu stricto from agricultural, ornamental, and several wild plants; and a second cluster comprised Ditylenchus spp. with polyploid chromosome numbers and was further subdivided into different subclades, one of which included the $D$. dipsaci giant race from $V$. faba. Our results in a similar phylogenetic analysis gave identical results and grouped the populations from garlic and sugar beet as members of $D$. dipsaci sensu stricto. Also, all sequences of $D$. dipsaci from $V$. faba obtained from GenBank (M. Kerkoud, M. Esquibet, O. Plantard, M. Avrillon, C. Guimier, M. Franck, J. Lechappe, and R. Mathis, unpublished results) grouped with isolates of Ditylenchus spp. B giant type from V. faba (38), which identified those isolates as members of the giant type. PCR assays using the SCAR primer pair H05/H06 (9) also identified populations from garlic and sugar beet as members of the normal type.

In the Mediterranean Basin, D. dipsaci has been reported to cause crop damage on carrot, faba bean, garlic, onion, and strawberry from fall to spring, when conditions are conducive to the establishment and development of the nematode. These conditions are characterized by soil temperature below $25^{\circ} \mathrm{C}$ and soil moisture suitable for plant growth, and conditions where plants may remain wet for several hours

Table 1. Host suitability of crops currently used and those with potential use in rotation with sugar beet areas infested by Ditylenchus dipsaci at Lebrija, Seville, Spain ${ }^{v}$

\begin{tabular}{lcc}
\hline Potential host crop & $\begin{array}{c}\text { Final nematode population } \\
\text { in soil' }\end{array}$ & $\boldsymbol{R f}^{\mathbf{x}}$ \\
\hline Onion (Allium cepa 'Valenciana') & $579.0 \pm 121.4^{\mathrm{y}} \mathrm{a}$ & $12.417 \mathrm{a}$ \\
Spinach (Spinacia oleracea 'Viroflay') & $454.7 \pm 72.6 \mathrm{~b}$ & $13.542 \mathrm{a}$ \\
Pea (Pisum sativum 'Lincoln') & $439.5 \pm 41.8 \mathrm{~b}$ & $17.879 \mathrm{a}$ \\
Sugar beet (Beta vulgaris 'Abril') & $415.2 \pm 12.4 \mathrm{~b}$ & $2.523 \mathrm{bc}$ \\
Potato (Solanum tuberosum 'Kennebec') & $405.8 \pm 31.5 \mathrm{~b}$ & $5.680 \mathrm{~b}$ \\
Bean (Phaseolus vulgaris 'Nectar') & $394.0 \pm 12.4 \mathrm{bc}$ & $0.016 \mathrm{~d}$ \\
Tobacco (Nicotiana tabacum 'NC 95') & $381.3 \pm 38.4 \mathrm{bc}$ & $0^{\mathrm{z}}$ \\
Cotton (Gossypium hirsutum 'Conchita') & $334.3 \pm 66.6 \mathrm{~cd}$ & $0.001 \mathrm{~d}$ \\
Tomato (Lycopersicon esculentum 'Tres Cantos') & $315.7 \pm 62.1 \mathrm{~d}$ & $1.431 \mathrm{c}$ \\
Maize (Zea mays 'Simon') & $291.2 \pm 96.6 \mathrm{~d}$ & $0.004 \mathrm{~d}$ \\
\hline
\end{tabular}

${ }^{\mathrm{v}}$ Data are average of two experiments each with six replicated plants per treatment combination. Plants were inoculated with 400 nematodes $(P i)$ of $\mathrm{D}$. dipsaci. Means followed by common letters in a column are not significantly different $(P \geq 0.05)$ according to Fisher's protected least significant difference test. Analyses were carried out using $\log _{10}(X+1)$ transformed data, but means of untransformed data are tabulated.

${ }^{\mathrm{w}}$ Assessed in artificially infested soil of each plant species 45 days after inoculation.

x Final nematode density in aboveground organs per plant (except for sugar beet, in which nematodes detected in the storage root were also considered)/initial nematode inoculum per plant.

y Standard error of the means.

${ }^{\mathrm{z}}$ Because there was no infection of aboveground plant parts of tobacco, data obtained from this crop were not included in the analysis, to avoid use of zero in analysis of variance. because of rain, fog, dew, and sprinkler irrigation (34). Our data demonstrate that $\mathrm{J} 4$ is the largest proportion of $D$. dipsaci life-stages occurring in sugar beet fields by the end of the crop season, both in the soil and in storage root tissue. This confirms previous findings $(6,16)$ and is of relevance for nematode survival to the next crop.

The development of crown canker in sugar beet by $D$. dipsaci may be a result of root invasion by the nematode at about soil level in late fall or early winter, which leads to the severe rot of crown tissues that can be observed toward the end of the crop growing season (6). Our results indicated also that most of the nematode infections were located at the crown-root region. These data agree well with infections of storage roots of carrots by $D$. dipsaci under field conditions in southern Italy reported by Greco et al. (16), who observed that the higher infections by the nematode occurred in carrot storage root tissues next to ground level. The initial penetration of stems by the nematode triggers a series of metabolic changes in host tissue that spread from the penetration sites into and along the carrot stolon. These metabolic changes cause structural modifications of host tissues including cell separation, swelling, and/or collapse, which allow nematodes to move around within host tissues $(27,31)$, similar to the findings in our study (Fig. 5), including cell separation.

The absence of leaf and petiole distortion (bloating and galling) in sugar beets during our field observations suggests that infections of those organs by $D$. dipsaci might have occurred rather early, at the young seedling stage by the end of winter or the beginning of spring, when environmental conditions of mild and rainy weather may favor nematode infection (6). Those early-infected tissues would have later degraded and disappeared and could not be perceived by the time of late samplings. These results agree with those described in sugar beet in Morocco (1), where collar rot started with infections of seedlings by $D$. dipsaci that caused swellings below the cotyledons and brown patches at the base of the petiole. Later, when the weather became hot, the plants partially recover, and as collar rot developed, 30 to $40 \%$ of the stem nematodes left the aboveground plant tissues.

More than 100,000 ha are grown to sugar beet (10) in Spain, of which about 37,000 ha are at the southern part of the country (25). A net reduction of this sugar beet growing area is expected in the near future as a result of the agricultural policy of the European Union, which aims to reduce production quotas across member states and remove subsidies (12), which points out a need of alternative crops to sugar beet in the most traditional areas. Similar circumstances are currently affecting cotton hectarage in southern Spain, 
which together with sugar beet is one of the largest and most profitable crops in this important irrigated agricultural area. This will force farmers to look for new alternative crops, which should be selected considering the risk of being infected by $D$. dipsaci if sown in soils infested with this nematode. We believe that the host-range characterization of the $D$. dipsaci population found in sugar beet fields in southern Spain would be useful information for making decisions about crop choice. Our finding on the host suitability of tomato for D. dipsaci demonstrated that this plant can maintain or even increase the nematode population density in infested soils. This agrees with Griffin (17), who reported reproduction and pathogenicity of $D$. dipsaci on tomato. In addition to crop choice, care should be taken concerning weed infestations in cropping soils, since many weeds have been shown to be hosts for the sugar beet race of $D$. dipsaci: chickweed, bedstraw, field mustard, wild radish, wild oats, and common groundsel (34). Conversely, some plants either are not infected or are infected slightly and rarely, and can therefore be suitable choices as alternative crops to sugar beet: wheat, barley, red clover, cabbage, and Swedish turnip (34).

Further studies are needed to determine the damage threshold levels of $D$. dipsaci to sugar beet since such information would be of use for establishing appropriate control measures in sugar beet fields infested by the nematode in order to reduce nematode infestation to a nondamaging level.

\section{ACKNOWLEDGMENTS}

This research was partially supported by grant "Marina Bueno" from the Spanish National Research Council (C.S.I.C.) and the Italian National Research Council (C.N.R.). The authors thank J. A. Navas-Cortés for reviewing the manuscript prior to submission and J. Martín Barbarroja for technical assistance. B. B. Landa is a contract holder of the 'Ramón y Cajal' program of the Ministerio de Educación y Ciencia of Spain.

\section{LITERATURE CITED}

1. Abbad Andaloussi, F., and Bachikh, J. 2001. Studies on the host range of Ditylenchus dipsaci in Morocco. Nematol. Mediterr. 29:51-57.

2. Castillo, P., Trapero-Casas, J. L., and JiménezDíaz, R. M. 1995. Effect of time, temperature, and inoculum density on reproduction of Pratylenchus thornei in carrot disk cultures. J. Nematol. 27:120-124.

3. Caubel, G. 1990. Beet nematodes: Combination of control methods. Cultivar Paris 279:5456.

4. Coolen, W. A. 1979. Methods for extraction of Meloidogyne spp. and other nematodes from roots and soil. Pages 317-329 in: Root-knot Nematodes (Meloidogyne species). Systematics, Biology, and Control. F. Lamberti and C. E. Taylor, eds. Academic Press, New York.

5. Dann, C., Gentzsch, D., and Schuler, H. 1981. Damage to sugar beet by Ditylenchus dipsaci pathogenic to onion. Nachr. Pflanz. DDR 35:82-83

6. Dunning, R. A. 1956. Beet stem eelworm. Nematologica 1:189-201.

7. Ebrahimi, N., Kheiri, A., and Pakniat, M. 2004. Occurrence of plant parasitic nematodes (Tylenchina) in sugar beet fields in Fars Province, Iran. Comm. Agric. Appl. Biol. Sci. 69:397-401.

8. Esquibet, M., Bekal, S., Castagnone-Sereno, P., Gauthier, J. P., and Caubel, G. 1998. Differentiation of normal and giant Vicia faba populations of the stem nematode Ditylenchus dipsaci: Agreement between RAPD and phenotypic characteristics. Heredity 81:291298.

9. Esquibet, M., Grenier, E., Plantard, O., Abbad Andaloussi, F., and Caubel, G. 2003. DNA polymorphism in the stem nematode Ditylenchus dipsaci: Development of diagnostic markers for normal and giant races. Genome 46:1077-1083.

10. FAOSTAT data, 2006. Published online on the FAOSTAT website. Food and Agriculture Organization of the United Nations.

11. Felt, H. 1959. Das stock- order stegelälchen Ditylenchus dipsaci (Kühn) Filipjev als Rübenschädling. Z. Zuckerind. 9:24-25.

12. Fischer Boel, M. 2005. The European sugar sector: Its importance and its future. European Commission.

13. Gomez, K. A., and Gomez, A. A. 1984. Statistical Procedures for Agricultural Research. 2nd ed. John Wiley \& Sons, New York.

14. Graf, A. E., Keller, E., Liechi, H., and Savary, A. 1960. Das Rübenkopfälchen. Vorläufiger bericht über versuche, untersuchungen und beobachtungen in der Schweiz in den Jahren 1958 und 1959. Mitt. Schweitz. Landwirtsch 8:33-48.

15. Graf, A., and Meyer, H. 1973. Importance of sugar beet stem eelworm in Switzerland and possibilities for control. J. Int. Inst. Sugar Beet Res. 6:117-126.

16. Greco, N., Brandonisio, A., and Boncoraglio, P. 2002. Investigations on Ditylenchus dipsaci damaging carrot in Italy. Nematol. Mediterr. 30:139-146.

17. Griffin, G. D. 1987. Interaction of Ditylenchus dipsaci and Meloidogyne hapla on resistant and susceptible plant species. J. Nematol. 19:441-446.

18. Grujicic, G. A. 1971. A contribution to the study of the stem nematode (Ditylenchus dipsaci Kuhn) with a review of the host plants in Serbia. Zastita Bilja 22:159-171.

19. Hawn, E. J. 1973. Plant-parasitic nematodes in irrigated soils of Alberta. Can. Plant Dis. Surv. 53:29-30.

20. Heijbroek, W. 1973. Forecasting incidence of, and issuing warnings about, nematodes, especially Heterodera schachtii and Ditylenchus dipsaci. IIRB J. Int. Inst. Sugar Beet Res. 6:7686.

21. Hooper, D. J. 1972. Ditylenchus dipsaci. C.I.H. Descriptions of Plant-parasitic Nematodes. Set 1, No. 14.

22. Johansen, D. A. 1940. Plant Microtechnique. McGraw-Hill, New York.

23. Kuthe, K. 1974. The effect of sugar beet nematode (Ditylenchus dipsaci Filipjev) infestation on the impurity percentage, sugar content and yield of sugar beet. Gesunde Pflanzen. 26:4857.

24. Manolache, C., and Romascu, E. 1973. Plant parasitic nematode found associated with cul- tivated plants in Rumania, present status and research perspectives. Nematol. Mediterr. 1:73-82.

25. MAPA, 2005. Avances de superficies y producciones agrícolas. Ministerio de Agricultura Pesca y Alimentación, Secretaría General Técnica, S. G. Estadísticas. Madrid, España. Centro de Publicaciones.

26. Nadasy, M., and Peter, J. 1981. Investigations into nematode populations in some major field crops in two remote areas in Hungary. Novenytermeles 30:163-167.

27. Riedel, R. M., and Mai, W. F. 1971. A comparison of pectinases from Ditylenchus dipsaci and Allium cepa callus tissue. J. Nematol. 3:174-178.

28. Roebuck, A., and Hull, R. 1937. The stem eelworm (Anguillulina dipsaci) attacks on sugar beet. J. Helminth. 15:243-245.

29. Schlang, J. 2004. Die Rübenkopffäule der Zuckerrübe verursacht durch das Rübenkopfälchen Ditylenchus dipsaci. 32 Tagung des Arbeitskreises Nematologie, 26-27 Mai 2004, Lundsgaard, Germany.

30. Schluter, K. A. 1972. First observations on lateral collar rot of sugar beet in Morocco. Awamia 43:95-107.

31. Seinhorst, J. W. 1956. Biologische rassen van het stengelaaltje Ditylenchus dipsaci (Kühn) Filipjev en hun waardplanten. I. Reacties van vatbare en resistente planten op aantasting en verschillende vormen van resistentie. Tijds. Planten. 62:179-188.

32. Seinhorst, J. W. 1966. Killing nematodes for taxonomic study with hot f.a. 4: 1. Nematologica 12:178.

33. Shcherbak, P. D., and Skarbilovich, T. S. 1973 The distribution of the sugar beet stem nematode and the damage inflicted by it in the Zaporozhye region. Byull. Vsesoyuz. Inst Gelmint. KI Skrjabina 11:95-97.

34. Sikora, R. A., Greco, N., and Veloso Silva, J. F. 2005. Nematode parasites of food legumes. Pages. 259-318 in: Plant Parasitic Nematodes in Subtropical and Tropical Agriculture. $M$ Luc, R. A. Sikora, and J. Bridge, eds. CABI Publishing, Wallingford, UK.

35. Sturhan, D. 1964. Interbreeding experiments with biological races of the stem eelworm (Ditylenchus dipsaci). Nematologica 10:328 334.

36. Sturhan, D. 1970. Ditylenchus dipsaci-doch ein Artenkomplex? Nematologica 10:327-328.

37. Sturhan, D., and Brzeski, M. W. 1991. Stem and bulb nematodes, Ditylenchus spp. Pages 423-464 in: Manual of Agricultural Nematology. W. R. Nickle ed. Marcel Dekker, Inc. New York.

38. Subbotin, S. A., Madani, M., Krall, E., Sturhan, D., and Moens, M. 2005. Molecular diagnostics, taxonomy, and phylogeny of the stem nematode Ditylenchus dipsaci species complex based on the sequences of the internal transcribed spacer-rDNA. Phytopathology 95:1308-1315.

39. Webster, J. M. 1967. The significance of biological races of Ditylenchus dipsaci and their hybrids. Ann. Appl. Biol. 59:77-83.

40. Wendt, K. R., Grain, T. C., and Webster, J. M 1993. Separation of three species of Ditylenchus and some host races of $D$. dipsaci by restriction fragment length polymorphism. J. Nematol. 25:555-563.

41. Yuksel, H. S. 1960. Observations on the life cycle of Ditylenchus dipsaci on onion seedlings. Nematologica 5:289-296. 